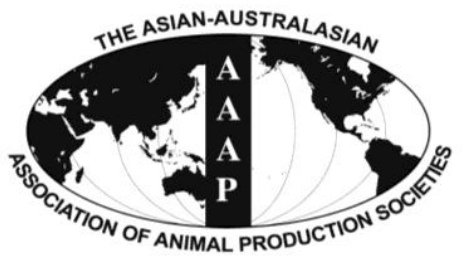

Asian-Aust. J. Anim. Sci.

Vol. 25, No. 12 : 1701-1711 December 2012

http://dx.doi.org/10.5713/ajas.2012.12372

www.ajas.info

pISSN 1011-2367 elSSN 1976-5517

\title{
Use of Awamori-pressed Lees and Tofu Lees as Feed Ingredients for Growing Female Goats
}

\author{
Itsuki Nagamine, Katsunori Sunagawa* and Tetsuya Kishi \\ Faculty of Agriculture, University of the Ryukyus, 1 Senbaru, Nishihara-cho, Okinawa 903-0213, Japan
}

\begin{abstract}
Okinawan Awamori is produced by fermenting steamed indica rice with black mold, yeast, and water. Awamori-pressed lees is a by-product of the Awamori production process. Tofu lees is a by-product of the Tofu production process. This research consisted of two experiments conducted to elucidate whether or not dried Awamori-pressed lees and Tofu lees can be used as a mixed feed ingredient for raising female goats. In experiment 1, digestion trials were conducted to ascertain the nutritive values of dried Awamoripressed lees and dried Tofu lees for goats. The digestible crude protein (DCP) and total digestible nutrients (TDN) contents of dried Awamori-pressed lees and Tofu lees were 22.5\%, 22.5\% (DCP), and 87.2\%, 94.4\% (TDN) respectively. In experiment 2, 18 female goats (Japanese Saanen $\times$ Nubian, three months old, body weight $15.4 \pm 0.53 \mathrm{~kg}$ ) were divided into three groups of six animals (control feed group (CFG), Awamori-pressed lees mixed feed group (AMFG), Tofu lees mixed feed group (TMFG)). The CFG control used feed containing $20 \%$ soybean meal as the main protein source, while the AMFG and TMFG treatments used feed mixed with $20 \%$ dried Awamori-pressed lees or dried Tofu lees. The groups were fed mixed feed (volume to provide $100 \mathrm{~g} / \mathrm{d}$ increase in body weight) twice a day (10:00, 16:00). The klein grass hay and water was given ad libitum. The hay intake was measured at 08:00 and 16:00. Body weight and size measurements were taken once a month. At the end of the experiment, a blood sample was drawn from the jugular vein of each animal. The DCP and TDN intakes in AMFG and TMFG showed no significant difference to the CFG. Cumulative measurements of growth in body weight, withers height, chest depth, chest girth, and hip width over the 10 mo period in the AMFG and TMFG were similar to the CFG. By contrast, cumulative growth in body length and hip height in the AMFG and TMFG tended to be larger than the CFG. Cumulative growth in chest width in the AMFG was significantly larger $(p<0.05)$ than the CFG. Blood parameter values were similar to those in normal goats reported by other scientists. The coats of the AMFG and TMFG animals looked shinier than the animals in the CFG. The results demonstrate that dried Awamori-pressed lees and Tofu lees can be used as a feed ingredient for the raising female goats. (Key Words: Awamori-pressed Lees, Tofu Lees, Growth, Body Size, Female Goat)
\end{abstract}

\section{INTRODUCTION}

In recent years, increased demands from the bio-ethanol industry, and drought and flood caused by climatic changes have been responsible for increases in the world price of grain (FAO, 2009; Scott et al., 2009). The rise in grain prices has had a profound effect on the management of dairy and meat producing farms in countries reliant on imported feed such as Japan. Because of this, the utilization of imported grain is decreasing and there is an urgent need to develop low cost locally produced sources of feed. We are focusing our attention on food by-products as an alternative to traditional imported feed.

In Okinawa, Awamori, the traditional spirit of the

\footnotetext{
* Corresponding Author: K. Sunagawa. Tel: +81-98-895-8798, Fax: +81-98-895-8734, E-mail: b986094@agr.u-ryukyu.ac.jp Submitted Jul. 3, 2012; Accepted Sept. 3, 2012; Revised Sept. 19, 2012
}

prefecture, is produced by combining steamed indica rice with black mold, yeast, and water. After fermentation, the mixture is distilled and the alcohol collected to produce the final product. The residue remaining after distillation is known as Awamori-distilled lees which consist of approximately $97 \%$ water. The solid matter remaining after pressing and squeezing to remove the excess fluid from the lees is called Awamori-pressed lees. Awamori-pressed lees are soft, highly viscous with low water content (54\%) and contain a high amount of nutritional and functional components. There are approximately 30,000 tons of Awamori-pressed lees produced each year that are being disposed of as waste. The lees are high in protein and spoil easily which make them incompatible for use as feed and thus they are treated as industrial waste and are disposed of.

In Okinawa, soy beans are soaked in water overnight and then ground, pressed, and squeezed to separate the soy milk from the solid matter. Tofu is made from soy milk and 
the by-product of the pressing and squeezing process is known as Tofu lees. Each year in Okinawa, approximately 800,000 tons of Tofu lees are disposed of due to the fact that their high water and protein content makes them incompatible for use as feed. Thus the majority of the lees are treated as industrial waste.

These lees are rich in nutritional components including protein, lipids, calcium, and bioactive functional components such as isoflavone, $\gamma$-aminobutyric acid (GABA), polyphenol, and citric acids (Inada et al., 2003; Genovese et al., 2006; Takaya et al., 2007). Because of this, it is thought that both Awamori-pressed lees and Tofu lees are capable of being used as feed, and in particular, as a source of protein.

Fujitani et al. (2000) reported that Holstein steers fed on a diet of full-fat rice bran mixed with Tofu lees gained equal amounts of weight as a control group fed on control feed.

Tamaki et al. (2005) fed Holstein milking cows for $6 \mathrm{wk}$ on a diet of feed mixed with $3 \%$ soy bean meal, and feed mixed with 3\% Awamori-pressed lees. The result was that there was no significant difference between the two feeds in terms of dry matter intake, body weight, and lactation performance. It is therefore reported that Awamori-pressed lees can be used as a substitute for soy bean meal in feed. However, the amount of Awamori-pressed lees and Tofu lees combined with basal feed was low, the length of time the mixed feed was supplied was short, and only body weight was measured in these reports. Therefore, it is unclear as to whether or not lees can be used as a source of feed for growing ruminants.

Growth and value of livestock is reflected in increases in body length, height, chest depth and width. Because of this, body length, height, and chest depth should be measured in any growth trials. To date however, there are no reports based on long term growth trials that detail the growth of goats in terms of increases in areas including body length, height and chest depth. Because of this, it is not clear if lees can be used as an ingredient in feed to raise ruminants.

The aim of this research was to demonstrate that Awamori-pressed lees and Tofu lees can be used as feed ingredients for rearing kids during growth periods. In order to achieve the research aims, experiment 1 elucidated the nutritive values for goats of Awamori-pressed lees and Tofu lees. In experiment 2, three types of feed were formulated; unmixed control feed (CF), feed combined with $20 \%$ dried Awamori-pressed lees (AMF - Awamori-pressed lees mixed feed), and feed combined with $20 \%$ dried Tofu lees (TMF Tofu lees mixed feed). The mixed feeds were fed to 3 month old female kids for a period of 10 mo. During that time, the growth of the goats was measured each month and the effects of feeding the animals with Awamori-pressed lees and Tofu lees were investigated.

\section{MATERIALS AND METHODS}

\section{Experiment 1: Nutritive value of Awamori-pressed lees and Tofu lees in goats}

Animals: Six adult male goats (crossbred Japanese Saanen/Nubian, aged $2.2 \pm 0.4 \mathrm{yr}$, weighing $49.7 \pm 8.29 \mathrm{~kg}$ ) were used in the experiment. The goats were maintained in individual metabolism cages (length $2 \mathrm{~m} \times$ width $1 \mathrm{~m} \times$ height $2 \mathrm{~m}$ ) that allowed for the separate collection of urine and feces. The laboratory room was maintained under thermoneutral conditions (room temperature $22.7 \pm 0.44^{\circ} \mathrm{C}$; relative humidity $85.7 \pm 1.42 \%$ ). In the preparatory period, the goats were given free access to drinking water and were fed $1.0 \mathrm{~kg}$ of roughly crushed alfalfa hay cubes twice daily at 10:00 and 16:00.

Measuring Awamori-pressed lees and Tofu lees digestibility: Six animals were separated into two groups of three animals each to measure digestibility using a cross over method. In the first experimental stage, group A was the control and was fed crushed alfalfa hay cubes. Group B, as the treatment, received crushed alfalfa hay cubes mixed with Awamori-pressed lees (AFL). This was reversed in the second experimental stage in which group A was the treatment and received the AFL alfalfa hay cube mix while group B, as the control, was fed alfalfa hay cubes.

In the control, animals received alfalfa hay cubes twice daily $(10: 00,1.0 \mathrm{~kg}, 16: 00,1.0 \mathrm{~kg})$ for $14 \mathrm{~d}$. In the AFL treatment, animals received $200 \mathrm{~g}$ of Awamori-pressed lees and $800 \mathrm{~g}$ of alfalfa hay cubes twice daily $(10: 00,1.0 \mathrm{~kg}$, $16: 00,1.0 \mathrm{~kg}$ ) for $14 \mathrm{~d}$. The animals were given free access to water throughout the experiment.

All of feces were collected from each individual animal for the final $6 \mathrm{~d}$ of each experimental stage. The floor at the back of the cages is made of mesh with a box placed beneath it. The excreted feces passed through the mesh and were collected in the box for measurement. The weight of the feces from each animal was measured each day and a $200 \mathrm{~g}$ sample was taken for further analysis. The feces samples were subjected to draught drying at $70^{\circ} \mathrm{C}$ for $24 \mathrm{~h}$. The dry weight of the feces was then measured. The dried feces were ground using a mixer (BM-FT08, Zojirushi Mahobin Co., Ltd). The samples from each animal taken over the $3 \mathrm{~d}$ period was combined and stored in a plastic bottle for analyzing the chemical composition.

Measurement of Tofu lees digestibility was carried out 1 mo after the conclusion of Awamori-pressed lees digestibility measurements and the same measurement methods were employed.

Calculation method for the digestibility of Awamoripressed lees and Tofu lees: The digestibility of alfalfa hay 
Table 1. Chemical composition of dried Awamori-pressed lees and dried Tofu lees

\begin{tabular}{lcc}
\hline & $\begin{array}{c}\text { Dried } \\
\text { Awamori-pressed } \\
\text { lees }\end{array}$ & $\begin{array}{c}\text { Dried } \\
\text { Tofu lees }\end{array}$ \\
\hline Dry matter (\%) & 97.9 & 91.8 \\
Chemical composition (\% DM) & & \\
$\quad$ Crude protein & 46.1 & 28.6 \\
Ether extracts & 15.7 & 14.3 \\
Crude fiber & 12.8 & 16.1 \\
Crude ash & 0.9 & 4.6 \\
$\quad$ Nitrogen free extracts & 24.5 & 36.4 \\
\hline
\end{tabular}

cubes, Awamori-pressed lees, and Tofu lees components was calculated using the following formula.

i) Digestibility of alfalfa hay cubes

Digestibility of each component $(\%)=($ amount of each component consumed-amount of each component excreted into the feces)/amount of each component consumed $\times 100$

ii) Digestibility of Awamori-pressed lees and Tofu lees

Digestibility of each component $(\%)=($ amount of each component consumed from lees-(amount of each component excreted into the feces-amount of each component in the feces derived from hay cube))/amount of each component consumed from the lees $\times 100$

Experiment 2: Use of Awamori-pressed lees and Tofu lees as a feed ingredient in raising female goats from weaning to maturity

Animals: Eighteen female kids (crossbred Japanese Saanen/Nubian goats, approximately 3 mo age, weighing $15.4 \pm 0.53 \mathrm{~kg}$ ) were used in this experiment. The animals were housed in three indoor farm pens (six animals per pen, length $4 \mathrm{~m} \times$ width $4 \mathrm{~m}$ ) attached feed trough (length $4 \mathrm{~m} \times$ width $0.3 \mathrm{~m} \times$ depth $0.25 \mathrm{~m}$ ) during both the preparatory feeding period and the experimental period.

Production of experimental feed mixed with Awamoripressed lees or Tofu lees: The Awamori-pressed lees was dried at $70^{\circ} \mathrm{C}$ for $8 \mathrm{~h}$ and then powdered to form an ingredient to produce the mixed feed used in the experiments. Tofu lees used as an ingredient in mixed feed

Table 2. Digestibility coefficients of dried Awamori-pressed lees and dried Tofu lees in adult goats

\begin{tabular}{lcc}
\hline $\begin{array}{c}\text { Digestibility } \\
\text { coefficients (\%) }\end{array}$ & $\begin{array}{c}\text { Dried } \\
\text { Awamori-pressed } \\
\text { lees }\end{array}$ & $\begin{array}{c}\text { Dried } \\
\text { Tofu lees }\end{array}$ \\
\hline Dry matter & 71.8 & 86.8 \\
Crude protein & 48.8 & 78.8 \\
Ether extracts & 94.4 & 93.4 \\
Crude fiber & 81.3 & 69.9 \\
Nitrogen-free extracts & 85.2 & 84.0 \\
\hline
\end{tabular}

Values are mean of six animals $(n=6)$.
Table 3. Ingredients of Control feed (CF), Awamori-pressed lees mixed feed (AMF) and Tofu lees mixed feed (TMF)

\begin{tabular}{lrrr}
\hline Ingredients (\%) & CF & AMF & TMF \\
\hline Wheat bran & 27.1 & 18.1 & 21.5 \\
Rolled corn & 43.0 & 42.0 & 35.0 \\
Alfalfa meal & 9.5 & 4.3 & 9.5 \\
Soy bean meal & 20.0 & 15.2 & 13.6 \\
Dried Tofu lees & 0.0 & 0.0 & 20.0 \\
Dried Awamori-pressed lees & 0.0 & 20.0 & 0.0 \\
Vitamin-mineral premix $^{1}$ & 0.3 & 0.3 & 0.3 \\
$\mathrm{CaCO}_{3}$ & 0.1 & 0.1 & 0.1 \\
Total & 100 & 100 & 100 \\
\hline
\end{tabular}

${ }^{1}$ Vitamin-mineral premix contained (DM basis): $2,511 \mathrm{mg} / \mathrm{kg}$ Fe; 750 $\mathrm{mg} / \mathrm{kg} \mathrm{Cu} ; 250 \mathrm{mg} / \mathrm{kg} \mathrm{Mn} ; 2,501 \mathrm{mg} / \mathrm{kg} \mathrm{Zn} ; 50,000 \mathrm{mg} / \mathrm{kg}$ Choline chloride; 1,000,000 IU/kg Vitamin A; 150,000 IU/kg Vitamin $\mathrm{D}_{3} ; 300$ $\mathrm{mg} / \mathrm{kg}$ Vitamin $B_{1} ; 1,000 \mathrm{mg} / \mathrm{kg}$ Vitamin $B_{2} ; 1,300 \mathrm{mg} / \mathrm{kg}$ Vitamin $B_{3}$; $1,100 \mathrm{mg} / \mathrm{kg}$ Vitamin $\mathrm{B}_{5} ; 600 \mathrm{mg} / \mathrm{kg}$ Vitamin $\mathrm{B}_{6} ; 125 \mathrm{mg} / \mathrm{kg}$ Vitamin $\mathrm{B}_{9} ;$ $1.5 \mathrm{mg} / \mathrm{kg}$ Vitamin $\mathrm{B}_{12} ; 5,000 \mathrm{mg} / \mathrm{kg}$ Vitamin E; and $267 \mathrm{mg} / \mathrm{kg}$ Vitamin $\mathrm{K}$.

was first subjected to $24 \mathrm{~h}$ of draught drying at $70^{\circ} \mathrm{C}$.

The three types of feed (control feed (CF), 20\% Awamori-pressed lees mixed feed (AMF), 20\% Tofu lees mixed feed (TMF), Table 3) made for use in this experiment were produced using the TDN and DCP values of Awamoripressed lees and Tofu lees that were elucidated in experiment 1 (Tables 1 and 2). All feeds were formulated to meet the nutrient requirements of growing female goats (NRC, 2006). The mixed feeds were produced to ensure that the DCP and TDN for all three feed types were virtually equal (Table 4). The feeds were designed to provide DCP and TDN levels equal to formulated mixed feed for calves currently available in the market.

Experimental design: The eighteen animals used in the experiment were separated into three groups of six animals (control group (CFG), Awamori-pressed lees group (AMFG), Tofu lees group (TMFG)). The average body weight of the animals in each group at the commencement of the experiment was virtually the same. The volume of mixed feed given to the animals was formulated to provide a $100 \mathrm{~g} / \mathrm{d}$ increase in body weight based on NRC feeding standards (NRC, 2006). For the first $3 \mathrm{mo}$, the animals were

Table 4. Chemical composition of control feed (CF), Awamoripressed lees mixed feed (AMF) and Tofu lees mixed feed (TMF)

\begin{tabular}{lrrr}
\hline & CF & AMF & TMF \\
\hline Dry matter (\%) & 85.9 & 88.3 & 86.9 \\
Chemical composition (\% DM) & & & \\
$\quad$ Crude protein & 20.5 & 24.7 & 21.3 \\
Ether extracts & 3.5 & 6.0 & 5.7 \\
Crude fiber & 6.3 & 6.8 & 8.6 \\
Crude ash & 5.5 & 4.4 & 5.4 \\
Nitrogen free extracts & 64.2 & 58.1 & 59.0 \\
DCP & 17.5 & 17.6 & 17.7 \\
TDN & 77.7 & 77.2 & 77.0 \\
\hline
\end{tabular}


given an allocation of $400 \mathrm{~g}$ DM per animal per day. Following this period, the allocation was increased to $500 \mathrm{~g}$ DM per animal per day and offered to the animals in equal portions at 08:00 and 16:00 (Table 5). The CFG, AMFG, and TMFG groups were given feed (control feed, Awamoripressed lees mixed feed, and Tofu lees mixed feed) allocated to each group (Tables 3 and 4). Klein grass hay and water were given ad libitum. The residual grass was removed from the feed box and the weight measured before new feed delivery at 08:00 and 16:00.

Over the 10 mo of the experiment, the index of growth of the animals was determined from monthly measurements of body weight, length, withers height, hip height, chest depth, width, girth, and hip width. Body weight was determined using a set of scales (Iconix New Zealand Ltd, New Zealand), chest girth was measured using a measuring tape, and the remainder of the measurements was determined using body size measurement apparatus (Fujihira Kougyou, Tokyo).

As an indicator of ruminal development, the amount of Klein grass hay consumed each day was measured. The consumed amount was determined by subtracting the weight of the residual grass from the total weight of grass given to the animals. A blood sample was taken from the animals before feeding on the last day of the experiment to analyze for hematocrit, hemoglobin and plasma parameters.

Chemical analysis of feed and feces: Alfalfa hay cubes, Awamori-pressed lees, Tofu lees and feces were ground with a Wiley mill (type 40-525P, screen size $1 \mathrm{~mm}$, Ikemoto Rika Kougyou, Tokyo, Japan). The chemical components of these feeds were quantified using the procedures described by the Japanese Feed Association (Kato, 1988). The moisture was measured using AOAC methods (AOAC, 1990). The CP content was calculated by multiplying nitrogen content by 6.25 of the feed and $\mathrm{N}$ was determined by Kjeldahl methods (AOAC, 1990). The ether extract (EE) was determined by subjecting the feed to a continuous extraction with ethyl ether for $16 \mathrm{~h}$ using Soxhlet methods (AOAC, 1990). The crude fiber (CF) was determined by subjecting the residual feed from ether extraction to successive treatments with boiling sulfuric acid and sodium hydroxide of $1.25 \%$ (AOAC, 1990). The ash was determined according to AOAC methods (AOAC, 1990). Moisture, ash, CP, EE and CF were subtracted from 100, to calculate nitrogen-free extracts (NFE).

Biochemical analysis of blood samples: Blood samples were placed in capillary tubes and centrifuged using a hematocrit centrifuge (HC-12A, Tomy Seiko, Tokyo, Japan; $12,851 \times g, 5 \mathrm{~min})$ to determine hematocrit by hematocrit reader (Tomy Seiko, Tokyo, Japan). Plasma total protein concentration and osmolality were measured using a refractometer (Atago, Tokyo, Japan) and an osmometer (OM-6010, Kyoto Daiichi Kagaku, Kyoto, Japan), respectively. Plasma glucose concentration was measured using a Spotchem EZ (SP-4430, Arkray, Tokyo, Japan). The plasma concentrations of $\mathrm{Na}, \mathrm{K}$, and $\mathrm{Cl}$ were measured using a Spotchem EL (SE-1520, Arkray, Kyoto, Japan).

Statistical analysis: In experiment 2, because six animals were reared in one pen, the amount of hay consumed by all six animals combined was recorded as the daily hay intake. The means and standard error of the means (SEM) of daily hay intakes per pen for $30 \mathrm{~d}$ in each month are shown in Table 5.

Body measurement and blood parameter values are shown as a mean value of the 6 animals in the group. A oneway analysis of variance and a subsequent Duncan's multiple range test were used to compare the daily intake of hay per pen in each month, body measurement, and blood

Table 5. Effect of feeding Awamori-pressed lees mixed feed (AMF) and Tofu lees mixed feed (TMF) on hay intake

\begin{tabular}{cccccc}
\hline Month $^{1}$ & $\begin{array}{c}\text { Mixed feed }^{2} \\
(\mathrm{~g} \mathrm{DM} / 6 \text { head/d })\end{array}$ & $\mathrm{CFG}^{4}$ & AMFG $^{5}$ & TMFG $^{3}$ & SEM $^{7}$ \\
\cline { 3 - 6 } & 2,400 & 1.28 & 1.23 & 1.24 & 0.009 \\
$4-4$ & 2,400 & 1.76 & 1.64 & 1.79 & 0.038 \\
$5-6$ & 2,400 & 2.26 & 2.24 & 2.23 & 0.004 \\
$6-7$ & 3,000 & 2.44 & 2.46 & $2.32^{*}$ & 0.006 \\
$7-8$ & 3,000 & 2.54 & 2.64 & 2.55 & 0.007 \\
$8-9$ & 3,000 & 3.00 & $3.11^{*}$ & 3.05 & 0.005 \\
$9-10$ & 3,000 & 3.00 & 3.08 & 2.91 & 0.007 \\
$10-11$ & 3,000 & 3.08 & 3.15 & $2.93^{*}$ & 0.009 \\
$11-12$ & 3,000 & 3.45 & 3.58 & 3.52 & 0.010 \\
$12-13$ & 3,000 & 4.15 & 4.10 & $3.80^{*}$ & 0.007 \\
\hline
\end{tabular}

\footnotetext{
${ }^{1}$ Age of animals.

${ }^{2}$ Amount of each mixed feed (control feed, Awamori-pressed lees mixed feed, Tofu lees mixed feed) for gaining $100 \mathrm{~g}$ per day were given.

${ }^{3}$ Because six animals were reared in one pen, the amount of hay consumed by all six animals combined was recorded as the daily hay intake. The mean and SEM of daily hay intakes per pen in each month $(30 \mathrm{~d})$ are shown.

${ }^{4}$ Control feed group. ${ }^{5}$ Awamori-pressed lees mixed feed group. ${ }^{6}$ Tofu lees mixed feed group. ${ }^{7}$ Standard error of the mean.

* Means of AMFG and TMFG in the same row are significantly different from CFG $(\mathrm{p}<0.05)$.
} 
parameters between control (CFG) and treatments (AMFG, TMFG). For statistical analysis, GLM procedure (SAS, 1990) was used.

All data were analyzed using the following model:

$$
\mathrm{Y}_{\mathrm{ij}}=\mu+\mathrm{T}_{\mathrm{i}}+\varepsilon_{\mathrm{ij}}
$$

Where $\mathrm{Y}_{\mathrm{ij}}=$ the measured variable; $\mu=$ the overall mean; $\mathrm{T}_{\mathrm{i}}=$ the effect of the $\mathrm{i}^{\text {th }}$ treatment; $\varepsilon_{\mathrm{ij}}=$ the random error effect.

\section{RESULTS}

\section{Experiment 1: Nutritive value of Awamori-pressed lees} and Tofu lees in goats

The chemical composition of Awamori-pressed lees and Tofu lees, and digestibility coefficients of these lees in goats are detailed in Table 1 and 2, respectively. Compared with other food by-products, the $\mathrm{CP}$ and $\mathrm{EE}$ contents of Awamori-pressed lees and Tofu lees were high while the NFE content was low. The CP and EE contents of Awamoripressed lees and Tofu lees were high. The digestibility coefficients of EE and NFE in Awamori-pressed lees were high while the digestibility coefficients of CP was low, $49 \%$ on average. On the other hand, the EE and NFE digestibility coefficients of Tofu lees was more than $80 \%$ while the digestibility coefficients of $\mathrm{CP}$ and $\mathrm{CF}$ was in the $70 \%$ range.
The digestible crude proteins (DCP) content of dried Awamori-pressed lees and dried Tofu lees for goats were $22.5 \%$ and $22.5 \%$, respectively. The TDN content of dried Awamori-pressed lees and dried Tofu lees for goats were $87.2 \%$ and $94.4 \%$, respectively.

Experiment 2: Use of Awamori-pressed lees and Tofu lees as a feed ingredient in raising female goats from weaning to maturity

Mixed feed and hay intake: Table 5 shows daily intake of mixed feeds (CF, AMF, TMF) and Klein grass hay.

As with $\mathrm{CF}$, the palatability of the AMF and TMF are high and the entire amount of feed given to the animals was consumed. The amount of hay consumed by AMFG and TMFG progressively increased over time and was particularly evident at 5, 8, 11, and 12 mo age. This was similar to CFG. The amount of hay being consumed by the groups at 13 mo age when the experiment was concluded had reached $4.0 \mathrm{~kg} / \mathrm{d} / 6$ head. During the experiment, the amount of hay consumed in the TMFG and the CFG was virtually equal. The amount of feed consumed in the AMFG after the animals passed the 6 mo age tended to be higher than the CFG.

The TDN and DCP intakes of the groups were calculated from mixed feeds and hay intakes. The TDN and DCP intake of the groups in the CFG, AMFG, and TMFG met the nutrient requirements for growing female goats as specified in the NRC feeding standards (NRC, 2006; Table 6).

Table 6. Total digestible nutrients (TDN) and digestible crude protein (DCP) intake levels in the CFG, AMFG, and TMFG

\begin{tabular}{|c|c|c|c|c|c|c|c|c|c|c|c|}
\hline \multirow{2}{*}{ Parameter } & \multirow{2}{*}{ Feed } & \multicolumn{10}{|c|}{ Age in month } \\
\hline & & 3 & 4 & 5 & 6 & 7 & 8 & 9 & 10 & 11 & 12 \\
\hline \multirow{4}{*}{$\begin{array}{l}\text { Required } \\
\text { (g DM/6 head/d) }\end{array}$} & & 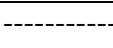 & & & -- Total d & gestible $n$ & atrients (T & DN) intak & ------- & ------ & --------- \\
\hline & $\mathrm{CFG}^{1}$ & $2,254.1$ & $2,508.7$ & $2,621.8$ & $2,887.7$ & $3,085.7$ & $3,153.6$ & $3,402.5$ & $3,521.3$ & $3,628.8$ & $3,826.8$ \\
\hline & $\mathrm{AMFG}^{2}$ & $2,265.4$ & $2,423.8$ & $2,604.9$ & $2,808.5$ & $2,989.6$ & $3,114.0$ & $3,379.9$ & $3,566.6$ & $3,736.3$ & $3,860.8$ \\
\hline & $\mathrm{TMFG}^{3}$ & $2,265.4$ & $2,452.1$ & $2,616.2$ & $2,859.4$ & $3,034.8$ & $3,198.9$ & $3,430.8$ & $3,515.7$ & $3,691.0$ & $3,900.4$ \\
\hline \multirow{3}{*}{$\begin{array}{l}\text { Intake } \\
\qquad(\mathrm{g} \mathrm{DM} / 6 \mathrm{head} / \mathrm{d})\end{array}$} & CFG & $2,288.2$ & $2,565.9$ & $2,856.5$ & $3,340.1$ & $3,394.6$ & $3,636.5$ & $3,637.8$ & $3,697.4$ & $3,922.2$ & $4,301.3$ \\
\hline & AMFG & $2,260.0$ & $2,491.2$ & $2,842.2$ & $3,350.6$ & $3,448.9$ & $3,708.8$ & $3,696.0$ & $3,739.7$ & $3,996.2$ & $4,271.3$ \\
\hline & TMFG & $2,263.6$ & $2,565.1$ & $2,744.6$ & $3,191.3$ & $3,310.9$ & $3,553.8$ & $3,476.4$ & $3,500.8$ & $3,837.5$ & $3,961.0$ \\
\hline \multirow{3}{*}{$\begin{array}{l}\text { Adequacy } \\
(\%)\end{array}$} & $\mathrm{CFG}$ & 101.5 & 102.3 & 109.0 & 115.7 & 110.0 & 115.3 & 106.9 & 105.0 & 108.1 & 112.4 \\
\hline & AMFG & 99.8 & 102.8 & 109.1 & 119.3 & 115.4 & 119.1 & 109.4 & 104.9 & 107.0 & 110.6 \\
\hline & TMFG & 99.9 & 104.6 & 104.9 & 111.6 & 109.1 & 111.1 & 101.3 & 99.6 & 104.0 & 101.6 \\
\hline \multirow{4}{*}{$\begin{array}{l}\text { Required } \\
(\text { g DM/6 head/d) }\end{array}$} & & & & & - Diges & ible crude & protein (I & CP) intak & & & \\
\hline & CFG & 200.4 & 223.9 & 234.4 & 259.0 & 277.3 & 283.6 & 306.6 & 317.5 & 327.5 & 345.8 \\
\hline & AMFG & 201.5 & 216.1 & 232.8 & 251.7 & 268.4 & 279.9 & 304.5 & 321.7 & 337.4 & 348.9 \\
\hline & TMFG & 201.5 & 218.7 & 233.9 & 256.4 & 272.6 & 287.7 & 309.2 & 317.0 & 333.2 & 352.6 \\
\hline \multirow{3}{*}{$\begin{array}{l}\text { Intake } \\
\qquad(\mathrm{g} \mathrm{DM} / 6 \mathrm{head} / \mathrm{d})\end{array}$} & CFG & 391.5 & 403.9 & 416.9 & 510.8 & 513.2 & 524.0 & 524.1 & 526.8 & 536.8 & 553.8 \\
\hline & AMFG & 390.2 & 400.5 & 416.2 & 511.2 & 515.7 & 527.3 & 526.7 & 528.7 & 540.1 & 552.4 \\
\hline & TMFG & 390.3 & 403.8 & 411.9 & 504.1 & 509.5 & 520.3 & 516.9 & 518.0 & 533.0 & 538.6 \\
\hline \multirow{3}{*}{$\begin{array}{l}\text { Adequacy } \\
(\%)\end{array}$} & $\mathrm{CFG}$ & 195.3 & 180.3 & 177.8 & 197.2 & 185.1 & 184.8 & 171.0 & 165.9 & 163.9 & 160.2 \\
\hline & AMFG & 193.7 & 185.3 & 178.8 & 203.2 & 192.1 & 188.4 & 173.0 & 164.3 & 160.1 & 158.3 \\
\hline & TMFG & 193.8 & 184.6 & 176.1 & 196.6 & 186.9 & 180.8 & 167.2 & 163.4 & 160.0 & 152.8 \\
\hline
\end{tabular}

Values are mean of TDN and DCP required level, intake level and adequacy per group in each month (30 d).

${ }^{1}$ Control feed group. ${ }^{2}$ Awamori-pressed lees mixed feed group. ${ }^{3}$ Tofu lees mixed feed group. 
Effects of feeding Awamori-pressed lees mixed feed $(A M F)$ and Tofu lees mixed feed (TMF) on growth: Table 7 shows the monthly body weight and size measurements of the animals in all three feed groups (CFG, AMFG, TMFG).

During the experiment, monthly body weight increases in the AMFG and TMFG were approximately the same as the CFG. There was no significant difference in body weights of the animals across the control and treatments.

Monthly increases in withers height, body length, and hip height in the AMFG and TMFG were approximately the same as the CFG during the experiment. There was no significant difference in monthly measured withers height in the AMFG and TMFG when compared to the CFG. By contrast, while there was no significant difference in monthly measured body length between the TMFG and
CFG, the body length of the animals in the AMFG at 13 mo of age tended to be longer than the CFG. No significant difference was found in monthly measured hip height between the TMFG and CFG. However, the hip height of the animals in the AMFG after 10 mo of age tended to be longer than the CFG. Significant difference was not found in the rate of monthly increases in chest depth, chest girth, and hip width in both the AMFG and TMFG when compared to the CFG. The chest width of the animals in the AMFG and TMFG tended to be approximately $1 \mathrm{~cm}$ narrower than the CFG animals at the start of the experiment. However, chest width of the animals in the AMFG and TMFG upon conclusion of the experiment tended to be 1 to $2 \mathrm{~cm}$ wider than that in the CFG.

Cumulative growth during the experimental period:

Table 7. Effect of feeding Awamori-pressed lees mixed feed (AMF) and Tofu lees mixed feed (TMF) on the growth of female goats

\begin{tabular}{|c|c|c|c|c|c|c|c|c|c|c|c|c|}
\hline \multirow{2}{*}{ Parameter } & \multirow{2}{*}{ Feed } & \multicolumn{11}{|c|}{ Age in month } \\
\hline & & 3 & 4 & 5 & 6 & 7 & 8 & 9 & 10 & 11 & 12 & 13 \\
\hline \multirow{4}{*}{$\begin{array}{l}\text { Body weight } \\
(\mathrm{kg})\end{array}$} & $\mathrm{CFG}^{1}$ & 15.3 & 19.8 & 21.8 & 26.5 & 30.0 & 31.2 & 35.6 & 37.7 & 39.6 & 43.1 & 48.4 \\
\hline & $\mathrm{AMFG}^{2}$ & 15.5 & 18.3 & 21.5 & 25.1 & 28.3 & 30.5 & 35.2 & 38.5 & 41.5 & 43.7 & 49.8 \\
\hline & $\mathrm{TMFG}^{3}$ & 15.5 & 18.8 & 21.7 & 26.0 & 29.1 & 32.0 & 36.1 & 37.6 & 40.7 & 44.4 & 48.9 \\
\hline & $\mathrm{SEM}^{4}$ & 0.98 & 1.36 & 1.82 & 1.81 & 1.93 & 1.86 & 2.26 & 2.59 & 2.30 & 2.88 & 3.46 \\
\hline \multirow{4}{*}{$\begin{array}{l}\text { Withers height } \\
\text { (cm) }\end{array}$} & $\mathrm{CFG}$ & 50.6 & 53.9 & 56.6 & 61.0 & 62.0 & 64.6 & 66.0 & 67.5 & 68.2 & 69.7 & 72.3 \\
\hline & AMFG & 51.2 & 53.7 & 56.1 & 58.6 & 61.5 & 64.0 & 66.0 & 68.2 & 68.9 & 70.3 & 73.1 \\
\hline & TMFG & 49.7 & 52.8 & 55.3 & 59.2 & 61.5 & 63.2 & 65.8 & 66.7 & 67.9 & 69.0 & 72.4 \\
\hline & SEM & 1.54 & 1.59 & 1.60 & 1.64 & 1.34 & 1.43 & 1.39 & 1.34 & 1.30 & 1.38 & 1.22 \\
\hline \multirow{4}{*}{$\begin{array}{l}\text { Body length } \\
(\mathrm{cm})\end{array}$} & $\mathrm{CFG}$ & 49.5 & 53.2 & 59.0 & 61.8 & 64.1 & 64.7 & 67.7 & 69.8 & 71.0 & 73.1 & 73.2 \\
\hline & AMFG & 48.4 & 52.9 & 58.1 & 62.3 & 64.6 & 66.5 & 69.6 & 70.0 & 71.1 & 72.5 & 75.8 \\
\hline & TMFG & 49.6 & 53.2 & 58.1 & 61.8 & 64.3 & 65.0 & 67.9 & 69.0 & 71.2 & 71.5 & 74.1 \\
\hline & SEM & 1.13 & 1.56 & 1.73 & 1.43 & 1.08 & 1.21 & 1.27 & 1.36 & 1.58 & 1.26 & 1.34 \\
\hline \multirow{4}{*}{$\begin{array}{l}\text { Hip height } \\
(\mathrm{cm})\end{array}$} & CFG & 50.0 & 54.6 & 58.0 & 60.1 & 62.4 & 64.5 & 66.5 & 67.5 & 68.4 & 70.2 & 71.7 \\
\hline & AMFG & 50.7 & 54.4 & 56.5 & 59.3 & 62.8 & 65.0 & 66.8 & 68.9 & 70.8 & 71.4 & 74.7 \\
\hline & TMFG & 50.4 & 55.0 & 57.1 & 59.0 & 63.3 & 63.9 & 66.5 & 67.5 & 68.6 & 69.3 & 73.4 \\
\hline & SEM & 1.24 & 1.43 & 1.57 & 1.59 & 1.73 & 1.44 & 1.50 & 1.48 & 1.49 & 1.52 & 1.56 \\
\hline \multirow{4}{*}{$\begin{array}{l}\text { Chest depth } \\
(\mathrm{cm})\end{array}$} & CFG & 20.8 & 22.1 & 23.3 & 25.2 & 26.8 & 27.1 & 28.9 & 29.3 & 30.5 & 30.9 & 32.5 \\
\hline & AMFG & 20.3 & 21.3 & 22.4 & 24.1 & 25.1 & 26.4 & 28.9 & 29.7 & 30.3 & 30.3 & 31.0 \\
\hline & TMFG & 20.5 & 21.8 & 23.0 & 25.2 & 26.0 & 26.8 & 28.6 & 29.6 & 29.9 & 31.0 & 31.7 \\
\hline & SEM & 0.83 & 0.78 & 0.78 & 0.75 & 0.78 & 0.69 & 0.90 & 0.82 & 0.61 & 0.56 & 0.78 \\
\hline \multirow{4}{*}{$\begin{array}{l}\text { Chest width } \\
(\mathrm{cm})\end{array}$} & CFG & 13.4 & 13.5 & 14.1 & 14.4 & 15.7 & 16.1 & 17.0 & 18.6 & 18.3 & 19.1 & 19.0 \\
\hline & AMFG & 12.4 & 12.9 & 13.4 & 14.5 & 15.9 & 16.1 & 17.5 & 17.5 & 18.1 & 19.3 & 20.9 \\
\hline & TMFG & 12.5 & 13.3 & 13.7 & 14.9 & 15.6 & 16.1 & 17.9 & 18.5 & 18.4 & 19.2 & 19.8 \\
\hline & SEM & 0.45 & 0.42 & 0.57 & 0.62 & 0.80 & 0.75 & 0.58 & 0.64 & 0.54 & 0.72 & 0.66 \\
\hline \multirow{4}{*}{$\begin{array}{l}\text { Chest girth } \\
(\mathrm{cm})\end{array}$} & CFG & 55.5 & 58.8 & 61.5 & 65.6 & 68.3 & 70.6 & 73.8 & 76.2 & 77.8 & 79.3 & 83.4 \\
\hline & AMFG & 56.0 & 56.3 & 59.3 & 63.3 & 65.7 & 68.2 & 72.4 & 74.4 & 76.3 & 78.8 & 82.7 \\
\hline & TMFG & 55.4 & 58.6 & 61.3 & 65.9 & 67.9 & 71.2 & 74.3 & 75.6 & 77.3 & 79.8 & 84.0 \\
\hline & SEM & 1.42 & 1.84 & 1.91 & 2.06 & 1.78 & 1.93 & 1.64 & 1.79 & 1.62 & 1.91 & 1.86 \\
\hline \multirow{4}{*}{$\begin{array}{l}\text { Hip width } \\
(\mathrm{cm})\end{array}$} & $\mathrm{CFG}$ & 9.7 & 10.4 & 11.0 & 12.0 & 12.8 & 13.4 & 14.1 & 14.3 & 14.6 & 15.1 & 16.0 \\
\hline & AMFG & 9.8 & 10.3 & 10.4 & 11.7 & 12.3 & 13.2 & 13.2 & 14.5 & 14.7 & 15.2 & 16.4 \\
\hline & TMFG & 10.5 & 10.5 & 10.8 & 11.9 & 12.3 & 13.4 & 13.5 & 14.1 & 14.7 & 14.9 & 15.8 \\
\hline & SEM & 0.34 & 0.27 & 0.37 & 0.39 & 0.34 & 0.34 & 0.38 & 0.32 & 0.34 & 0.32 & 0.41 \\
\hline
\end{tabular}

Values are mean of six animals $(n=6)$.

${ }^{1}$ Control feed group. ${ }^{2}$ Awamori-pressed lees mixed feed group. ${ }^{3}$ Tofu lees mixed feed group. ${ }^{4}$ Standard error of the mean.

No significant differences were observed among the three kinds of feeds $(p>0.05)$. 
Table 8. Effect of feeding Awamori-pressed lees mixed feed (AMF) and Tofu lees mixed feed (TMF) on cumulative growth of female goats

\begin{tabular}{lcccc}
\hline Parameter & CFG $^{1}$ & AMFG $^{2}$ & TMFG $^{3}$ & SEM $^{4}$ \\
\hline Body weight (kg/10 month) & 33.1 & 34.3 & 33.4 & 3.36 \\
Withers height (cm/10 month) & 21.7 & 21.9 & 22.7 & 1.28 \\
Body length (cm/10 month) & 23.7 & 27.5 & 24.5 & 1.63 \\
Hip height (cm/10 month) & 21.7 & 24.0 & 23.1 & 1.70 \\
Chest depth (cm/10 month) & 11.7 & 10.7 & 7.3 & 0.80 \\
Chest width (cm/10 month) & 5.5 & $8.5 *$ & 0.80 \\
Chest girth (cm/10 month) & 27.9 & 26.7 & 28.6 & 2.09 \\
Hip width (cm/10 month) & 6.4 & 6.5 & 5.4 & 0.54 \\
\hline
\end{tabular}

Values are mean of six animals $(n=6)$.

${ }^{1}$ Control feed group. ${ }^{2}$ Awamori-pressed lees mixed feed group. ${ }^{3}$ Tofu lees mixed feed group. ${ }^{4}$ Standard error of the mean.

* Means of AMFG and TMFG in the same row are significantly different from CFG $(\mathrm{p}<0.05)$.

Table 8 shows the cumulative growth of the animals during the 10 month experimental period.

While the cumulative increases in withers height in the AMFG and TMFG were virtually the same as the CFG, cumulative body length, hip height among the animals in the AMFG and TMFG tended to be greater than the animals in the CFG. Cumulative chest width among animals in the AMFG was significantly higher $(p<0.01)$ than the CFG while the animals in the TMFG tended to be higher than the CFG. Other cumulative measurements of the animals in both the AMFG and TMFG were not significantly different to the CFG animals.

The growth percentage of body parameters: Table 9 shows the growth percentage of body parameters based on the measurements taken throughout the experiment.

In the AMFG and TMFG, eighty percent of the withers height, body length, and hip height recorded at the conclusion of the experiment (13 mo old) were attained by the time the animals had reached 6 mo old. Eighty percent of the chest depth, width, girth, and hip width measured at 13 mo old were attained by the time they were 8 mo old. Eighty percent of the body weight measurements recorded at 13 mo old was attained by the time they were 11 mo old. These are similar to the animals in the CFG.

Blood composition analysis and physical observation: Table 10 shows the blood parameters on the animals in the CFG, AMFG and TMFG. The plasma total protein concentration in the AMFG was virtually the same as the animals in the CFG while the values in the TMFG animals were comparatively lower than the CFG $(\mathrm{p}<0.01)$. Plasma cholesterol concentrations, plasma HDL cholesterol concentrations, and plasma phospholipids concentrations in AMFG animals tended to be higher than the CFG animals. Plasma LDL cholesterol concentrations, and plasma nonestertified free fatty acid concentrations in both the AMFG and TMFG animals tended to be higher than the CFG. All other measurements in the AMFG and TMFG animals were the same as the CFG animals.

The coats of the animals in the AMFG and TMFG were observed to be shinier than the CFG animals. This was particularly apparent in the AMFG animals.

\section{DISCUSSION}

\section{Availability of food by-products for goats}

A large number of food by-products are nutritionally unbalanced. In order to use them as livestock feed the nutritional deficiency must be understood and the food byproduct combined with other feed to produce a nutritionally balanced final product (Saeki, 2007).

In Awamori-pressed lees, the rice starch has been used in the alcohol fermentation process. In the case of Tofu lees, the majority of the soy bean protein is used in the production of Tofu. Despite this, both by-products are high in nutritional elements such as protein and lipids, and bioactive functional substances such as citric acid, and isoflavones (Table 1; Inada et al., 2003; Genovese et al., 2006; Takaya et al., 2007).

The Awamori-pressed lees used in this experiment were high in CP content and had EE content similar to levels found in Tofu lees (Table 1). However, the digestibility coefficients of the protein was low (Table 2). On the other hand, the $\mathrm{CP}$ and EE content in the Tofu lees were high and digestibility coefficients of them in the Tofu lees was high (Tables 1 and 2). Awamori-pressed lees is the by-product remaining after the liquid component from Awamori lees has been separated to produce Moromi vinegar. When the Moromi vinegar component is removed, a significant proportion of digestible amino acids and water soluble proteins are also removed. This factor is thought to be the cause of the low digestibility of the Awamori-pressed lees.

The ether extracts content of dried Awamori-pressed lees and dried Tofu lees $(15.7 \%$, and $14.3 \%$ respectively) was substantially higher than levels found in corn and soy bean meal (Table 1, NARO, 2010).

\section{Experimental design}

The feed given to the animals in all three groups (CFG 
Table 9. The growth percentage of body parameters based on the measurements taken throughout the experiment

\begin{tabular}{|c|c|c|c|c|c|c|c|c|c|c|c|c|}
\hline \multirow{2}{*}{ Parameter } & \multirow{2}{*}{ Feed } & \multicolumn{11}{|c|}{ Age in month } \\
\hline & & 3 & 4 & 5 & 6 & 7 & 8 & 9 & 10 & 11 & 12 & 13 \\
\hline \multirow{4}{*}{$\begin{array}{l}\text { Body weight } \\
(\%)\end{array}$} & $\mathrm{CFG}^{1}$ & 32.3 & 41.3 & 45.3 & 55.2 & 62.4 & 64.8 & 73.7 & 77.9 & 81.9 & 88.9 & 100.0 \\
\hline & $\mathrm{AMFG}^{2}$ & 32.0 & 37.2 & 43.6 & 50.9 & 57.2 & 62.0 & 71.2 & 78.0 & 84.3 & 88.4 & 100.0 \\
\hline & $\mathrm{TMFG}^{3}$ & 31.8 & 38.9 & 44.7 & 53.5 & 60.0 & 65.9 & 74.2 & 77.1 & 83.7 & 90.8 & 100.0 \\
\hline & $\mathrm{SEM}^{4}$ & 2.74 & 2.96 & 3.56 & 3.21 & 3.11 & 2.83 & 2.56 & 2.16 & 1.78 & 1.61 & - \\
\hline \multirow{4}{*}{$\begin{array}{l}\text { Withers height } \\
(\%)\end{array}$} & CFG & 70.0 & 74.6 & 78.4 & 84.4 & 85.8 & 89.4 & 91.4 & 93.4 & 94.4 & 96.5 & 100.0 \\
\hline & AMFG & 70.0 & 73.4 & 76.7 & 80.1 & 84.1 & 87.5 & 90.3 & 93.2 & 94.2 & 96.2 & 100.0 \\
\hline & TMFG & 68.6 & 72.9 & 76.3 & 81.8 & 84.9 & 87.2 & 91.0 & 92.3 & 93.8 & 95.4 & 100.0 \\
\hline & SEM & 1.74 & 1.92 & 1.76 & 1.62 & 1.11 & 1.26 & 0.99 & 0.96 & 0.77 & 0.90 & - \\
\hline \multirow{4}{*}{$\begin{array}{l}\text { Body length } \\
(\%)\end{array}$} & CFG & 67.8 & 73.0 & 80.7 & 84.6 & 87.7 & 88.4 & 92.5 & 95.5 & 97.2 & 100.0 & 100.0 \\
\hline & AMFG & 63.8 & 69.7 & 76.7 & 82.1 & 85.2 & 87.6 & 91.8 & 92.2 & 93.7 & 95.7 & 100.0 \\
\hline & TMFG & 67.0 & 71.9 & 78.6 & 83.5 & 86.9 & 87.7 & 91.7 & 93.2 & 96.1 & 96.5 & 100.0 \\
\hline & SEM & 1.84 & 2.07 & 2.19 & 1.39 & 1.17 & 0.76 & 1.03 & 0.95 & 1.07 & 0.90 & - \\
\hline \multirow{4}{*}{$\begin{array}{l}\text { Hip height } \\
(\%)\end{array}$} & CFG & 69.8 & 76.3 & 81.0 & 83.9 & 87.1 & 90.1 & 92.9 & 94.3 & 95.5 & 98.1 & 100.0 \\
\hline & AMFG & 68.1 & 72.9 & 75.7 & 79.4 & 84.0 & 87.0 & 89.4 & 92.2 & 94.8 & 95.5 & 100.0 \\
\hline & TMFG & 68.6 & 75.0 & 77.7 & 80.3 & 86.2 & 87.1 & 90.5 & 91.8 & 93.3 & 94.3 & 100.0 \\
\hline & SEM & 1.94 & 1.93 & 1.85 & 1.74 & 1.64 & 1.31 & 1.33 & 0.87 & 0.85 & 0.90 & - \\
\hline \multirow{4}{*}{$\begin{array}{l}\text { Chest depth } \\
(\%)\end{array}$} & CFG & 64.0 & 68.1 & 71.7 & 77.5 & 82.6 & 83.5 & 89.2 & 90.3 & 94.1 & 95.4 & 100.0 \\
\hline & AMFG & 65.5 & 68.6 & 72.1 & 77.6 & 81.0 & 85.1 & 93.0 & 95.6 & 97.9 & 97.7 & 100.0 \\
\hline & TMFG & 64.5 & 68.7 & 72.5 & 79.5 & 81.9 & 84.7 & 90.2 & 93.5 & 94.3 & 97.9 & 100.0 \\
\hline & SEM & 2.31 & 1.90 & 1.73 & 1.61 & 1.71 & 1.53 & 2.00 & 1.82 & 1.76 & 1.33 & - \\
\hline \multirow{4}{*}{$\begin{array}{l}\text { Chest width } \\
(\%)\end{array}$} & $\mathrm{CFG}$ & 71.7 & 72.0 & 74.6 & 76.4 & 82.7 & 85.0 & 90.4 & 98.3 & 96.8 & 100.7 & 100.0 \\
\hline & AMFG & 59.5 & 61.7 & 64.0 & 69.5 & 75.7 & 76.9 & 83.7 & 83.8 & 86.3 & 92.1 & 100.0 \\
\hline & TMFG & 63.2 & 67.3 & 69.3 & 75.6 & 79.1 & 81.8 & 90.9 & 93.7 & 93.3 & 97.3 & 100.0 \\
\hline & SEM & 3.10 & 3.12 & 3.05 & 3.55 & 3.40 & 3.13 & 3.19 & 2.11 & 1.77 & 2.23 & - \\
\hline \multirow{4}{*}{$\begin{array}{l}\text { Chest girth } \\
(\%)\end{array}$} & $\mathrm{CFG}$ & 66.6 & 70.6 & 73.7 & 78.6 & 81.8 & 84.6 & 88.5 & 91.3 & 93.3 & 95.1 & 100.0 \\
\hline & AMFG & 68.0 & 68.1 & 71.7 & 76.5 & 79.4 & 82.4 & 87.5 & 90.0 & 92.2 & 95.2 & 100.0 \\
\hline & TMFG & 66.1 & 69.3 & 73.0 & 78.5 & 80.9 & 84.7 & 88.4 & 90.1 & 92.1 & 95.1 & 100.0 \\
\hline & SEM & 2.02 & 2.12 & 1.69 & 1.98 & 1.54 & 1.51 & 1.02 & 0.92 & 0.74 & 0.96 & - \\
\hline \multirow{4}{*}{$\begin{array}{l}\text { Hip width } \\
(\%)\end{array}$} & CFG & 60.4 & 65.2 & 69.0 & 75.0 & 80.0 & 83.7 & 87.9 & 89.3 & 91.3 & 94.3 & 100.0 \\
\hline & AMFG & 60.4 & 63.3 & 63.6 & 71.5 & 75.0 & 80.6 & 81.0 & 88.9 & 89.9 & 93.0 & 100.0 \\
\hline & TMFG & 66.4 & 66.5 & 68.3 & 75.0 & 77.9 & 84.7 & 85.2 & 88.9 & 92.9 & 94.4 & 100.0 \\
\hline & SEM & 2.67 & 1.89 & 1.76 & 1.80 & 1.27 & 1.13 & 2.22 & 1.82 & 1.51 & 1.43 & - \\
\hline
\end{tabular}

Values are mean of six animals $(n=6)$.

Values were calculated by the data measured in each month divided by the data measured in 13 month.

${ }^{1}$ Control feed group. ${ }^{2}$ Awamori-pressed lees mixed feed group. ${ }^{3}$ Tofu lees mixed feed group. ${ }^{4}$ Standard error of the mean.

No significant differences were observed among the three kinds of feeds $(p>0.05)$

control, AMFG treatment, TMFG treatment) was formulated to ensure that irrespective of the mixed feed being used, the TDN and DCP content were the same, satisfied the NRC standards (2006), and produced a daily body weight gain of $100 \mathrm{~g} / \mathrm{d}$. The three month old kids were fed an equal amount of the mixed feed designated for their group for 10 mo (Tables 3 and 4). It was investigated whether or not the animals fed on mixed feed in the AMFG and TMFG treatments grew at the same rate as the animals fed on control feed in the CFG. The results allow clarification as to whether or not Awamori-pressed lees and Tofu lees can be used as a feed ingredient for the rearing of goats.

\section{Feeding and growing of kids goats}

While goats are herbivores, the rumino-reticulum of newly weaned kids is not sufficiently developed and which makes it impossible for the animals to satisfy their nutrient requirements for growth by feeding exclusively on grass (Lengemann and Allen, 1955). This is especially so for kids fed on dried grass. The addition of vitamins, minerals, and protein to the feed is essential. It has been reported that by increasing the CP content in feed, daily body weight gain in kids and calves can be increased (Cheema et al., 1991; Pathak et al. 1992; Jia et al. 1995; Negesse et al., 2001). The difference between the control and the treatments was that the main protein source in the control feed used in the CFG control was soy bean meal while the main protein 
Table 10. Effect of feeding Awamori-pressed lees mixed feed (AMF) and Tofu lees mixed feed (TMF) on blood parameters in female goats

\begin{tabular}{|c|c|c|c|c|}
\hline Plasma component & $\mathrm{CFG}^{1}$ & $\mathrm{AMFG}^{2}$ & $\mathrm{TMFG}^{3}$ & $\mathrm{SEM}^{4}$ \\
\hline Hematocrit (\%) & 35.9 & 33.5 & 35.9 & 1.58 \\
\hline Blood hemoglobin (g/dl) & 10.2 & 9.6 & 9.6 & 0.46 \\
\hline Plasma osmolality (mOsm/L) & 289.5 & 290.0 & 289.0 & 1.20 \\
\hline Plasma total protein $(\mathrm{g} / \mathrm{dl})$ & 6.8 & 6.6 & $6.3 *$ & 0.10 \\
\hline Plasma glucose (mg/dl) & 76.2 & 75.3 & 74.3 & 2.48 \\
\hline Plasma albumin (g/dl) & 3.5 & 3.5 & 3.4 & 0.09 \\
\hline Plasma Na (mmol/L) & 136.5 & 136.0 & 135.3 & 0.57 \\
\hline Plasma K (mmol/L) & 5.0 & 4.6 & 4.6 & 0.21 \\
\hline Plasma Cl (mmol/L) & 98.8 & 99.3 & 98.0 & 0.83 \\
\hline Plasma GOT (IU/L) & 87.0 & 89.0 & 81.2 & 10.37 \\
\hline Plasma GPT (IU/L) & 22.7 & 20.3 & 16.0 & 3.21 \\
\hline Plasma total cholesterol (mg/dl) & 80.9 & 97.9 & 87.0 & 5.21 \\
\hline Plasma triglyceride (mg/dl) & 35.2 & 34.0 & 33.0 & 3.95 \\
\hline Plasma HDL cholesterol (mg/dl) & 48.1 & $58.7 *$ & 49.1 & 2.64 \\
\hline Plasma LDL cholesterol (mg/dl) & 25.7 & 32.4 & 31.2 & 2.92 \\
\hline Plasma free fatty acid $(\mu \mathrm{Eq} / \mathrm{L})$ & 203.0 & 311.7 & 303.5 & 39.65 \\
\hline Plasma phospholipids (mg/dl) & 116.2 & 132.5 & 118.7 & 6.46 \\
\hline
\end{tabular}

Values are mean of six animals $(n=6)$.

${ }^{1}$ Control feed group. ${ }^{2}$ Awamori-pressed lees mixed feed group. ${ }^{3}$ Tofu lees mixed feed group. ${ }^{4}$ Standard error of the mean.

* Means of AMFG and TMFG in the same row are significantly different from CFG $(\mathrm{p}<0.05)$.

source in the AMFG and TMFG treatments was respectively derived from the Awamori-pressed lees and the Tofu lees (Table 3).

Grass silage intake in sheep and cows is substantially lower than hay intake (Anil et al., 1993). However, the Awamori-pressed less, a fermentative by-product, and the Tofu lees palatability was very high for female goats from weaning to maturity. Because of this palatability, the growing female goats ( 3 months old to 13 months old) were able to satisfy their TDN and DCP requirements (Table 6).

Among the animals in the groups in this experiment, none were observed to be noticeably stronger or weaker than the others in the group. Because of this, the SEM of growth parameters in each group is low (Tables 5 and 7). Each group in the experiment was fed 2,400 g DM/d/6 head from 3 months old to 6 months old. This was increased to 3,000 g DM/d/6 head from 7 months old to 13 months old (Table 5). It is therefore estimated that each animal in the group consumed $400 \mathrm{~g} \mathrm{DM} / \mathrm{d} /$ head of mixed feed from 3 months old to 6 months old and $500 \mathrm{~g} \mathrm{DM} / \mathrm{d} /$ head from 7 months old to 13 months old.

\section{Body measurements in growing female goats}

Female goats with very good body proportions typically yield a higher sale price. In other words, what buyers look for are a straight dorsal line, long body length, good height, wide body, and a deep chest. Females with bony framework are highly valued as robust breeding animals. It is thought that nutritional factors are involved in the extent of body growth (Bortone et al., 1994).
Until now, the aim of livestock production has been to increase body weight gain and therefore there are few papers reporting size increases in other areas of an animal's physique (Bortone et al., 1994). However, growth is not simply an increase in body weight. Body weight increase occur an increase in all parts of the animals' body such as body length, body height, chest width and depth, and therefore it is thought that evaluating growth as a factor of body weight gain alone is insufficient.

This research reports the growth of kids over a 10 month period in terms of not only body weight gain but also in terms of size increases in the animals body parts (Tables 7 and 8). Increases in withers height, body length, and hip height show increases in skeletal size of the animal. At the end of the experiment (13 mo old), skeletal size had increased in these areas by an average of approximately $31.9 \%$. Chest depth, width, girth, and hip width measurements represent expansion of the body capacity in order to accommodate the visceral organs. These areas had increased by an average of $34.8 \%$ by the end of the experiment (13 mo old). In contrast, body weight increases at the end of the experiment were approximately $68.5 \%$.

Body weight increases over the 10 month period of the experiment in the AMFG and TMFG treatments were the same as increases recorded in the CFG control. On the other hand, cumulative increases in body length and hip height over the 10 month experimental period tended to be higher in the AMFG and TMFG treatments when compared to the CFG control. Compared with the CFG control, cumulative increases in chest width tended to be higher in the TMFG 
treatment, and was significantly higher in the AMFG treatment $(p<0.01)$. These results indicate that skeletal size may potentially be promoted by feeding animals Awamoripressed lees and Tofu lees. Also, these results indicate that animals in the AMFG and TMFG grew normally like animals in the CFG (Tables 7 and 8).

\section{Bioactive functions of Awamori-pressed lees and Tofu lees}

The main ingredient in the mixed feed used in the CFG control was corn or soy bean meal. These ingredients have a fat content of $4.2 \%$ and $1.2 \%$, respectively. By contrast, the main ingredient of Awamori is rice with a very low fat content of $0.5 \%$ (NARO, 2010). Despite the low fat content of rice, the fat content of dried Awamori-pressed lees is a very high $15.7 \%$ (Table 1). The fat content in Awamoripressed lees is similar to that in shochu (distilled spirit produced in Kyushu) lees which is also made from rice (NARO, 2010).

Furthermore, Awamori-pressed lees and Tofu lees contain substantial amounts of bio-active functional components such as isoflavones, GABA, polyphenols, and citric acid (Inada et al., 2003; Genovese et al., 2006; Takaya et al., 2007). It has been reported that these bio-active functional components block bone resorption activity, promoted bone formation activity (Fujioka et al., 2007; Thang et al., 2010), improve lipid metabolism, blood flow, possess tranquilization effects, and antioxidant activity in rats (Okada et al., 2000; Álvarez et al., 2006; Fukuda et al., 2006; Barbosa et al., 2010). Compared to the CFG control, body length, withers height and hip height in the AMFG and TMFG treatments were larger. This may be caused by increase of bone growth due to the actions of phospholipids and bioactive functional components.

The blood parameters in the AMFG and TMFG were similar to that of the CFG. The blood parameters in this experiment were similar to the values obtained from a normal female goat (Mbassa and Poulsen, 1991; Kokkonen et al., 2001; Eiselt et al., 2011; Skotnicka et al., 2011).

The results indicate that feeding goats mixed feed containing $20 \%$ of Awamori-pressed lees or Tofu lees contributes to the overall quality of the animals including normal growth and maintained normal body condition as same as feeding goats control feed containing no lees.

Despite a significant amount of the starch and protein being utilized in the production of Awamori and Tofu, a high amount of nutritional components including protein and lipids still remain in the Awamori-pressed lees and Tofu lees.

This experiment demonstrates that Awamori-pressed lees and Tofu lees can be used as feed ingredient for rearing female goats during growth periods.
The results of this experiment suggest that through developing new types of feed ingredients, significant contribution can be made in addressing the feed cost issues faced by farmers.

\section{ACKNOWLEDGMENTS}

We thank Mr. Takashi Kina, Mr. Yasuhiro Izutsu, Mr. Yu Tokoro, Miss Ayano Matayoshi, Mr. Tomoyuki Namima, Mr. Daisuke Nakama for their helpful assistance in experiments and recording the data. We thank Mr. Masahide Shinjo, the owner of Hagoromo Farm where this experiment was conducted. We also thank Mr. Glenn McIlvride for his English proof-reading on this manuscript. The computation was mainly carried out using the computer facilities in Research Institute for Information Technology, Kyushu University.

\section{REFERENCES}

Álvarez, P., C. Alvarado, F. Mathieu, L. Jiménez and M. De la Fuente. 2006. Diet supplementation for 5 weeks with polyphenol-rich cereals improves several functions and the redox state of mouse leucocytes. Eur. J. Nutr. 45:428-438.

Anil, M. H., J. N. Mbanya, H. W. Symonds and J. M. Forbes. 1993. Responses in the voluntary intake of hay or silage by lactating cows to intraruminal infusions of sodium acetate, sodium propionate or rumen distension. Br. J. Nutr. 69:699-712.

AOAC. 1990. Official methods of analysis. 15th Ed. Association of Official Analytical Chemists, Arlington, Virginia, USA.

Barbosa, A. C. L., F. M. Lajolo and M. I. Genovese. 2011. Effect of free or protein-associated soy isoflavones on the antioxidant status in rats. J. Sci. Food Agric. 91:721-731.

Bortone, E. J., J. L. Morrill and J. S. Stevenson. 1994. Growth of heifers fed 100 or $115 \%$ of National Research Council requirements to 1 year of age and then changed to another treatment. J. Daily Sci. 77:270-277.

Cheema, A. U., M. L. Galyean, J. S. Caton and A. S. Freeman. 1991. Influence of protein levels and naloxone on intake, nitrogen metabolism and digestion kinetics in lambs fed oat hay or barley straw. Small Rumin. Res. 5:35-46.

Eiselt, N., H. Wagner and A. Wehrend. 2011. Haematologic parameters in goats. Ieraerztliche Praxis Ausgabe Grosstiere Nutztiere 39:49-55.

Fao. 2008. The Investment Imperative, paper from the FAO High Level Conference on World Food Security: The Challenges of Climate Change and Bioenergy. Food and Agriculture Organization, Rome.

Fujioka, M., Y. Sudo, M. Okumura, J. Wu, M. Uehara, K. Takeda, Y. Hosokawa, K. Yamada, S. Ikegami and Y. Ishimine. 2007. Differential effects of isoflavones on bone formationin growing male and female mice. Metabolism 56:1142-1148.

Fujitani, Y., S. Nobuhara, S. Ohtani, K. Nishimura, S. Mohri and T. Ohishi. 2000. Effect of both full-fat rice bran and Tofu cake diets on feed intake and weight grain in Holstein steers. Bulletin of Osaka Agriculture and Forestry Research Center 
36:48-52.

Fukuda, M., Y. Sugihara, M. Itou, R. Horiuchi and H. Asao. 2006. Effects of feeding with Okara on plasma and liver lipid levels in rats. Nippon Shokuhin Kagaku Kogaku Kaishi (Jpn.) 53: 195-199.

Genovese, M. I., J. Davila and F. M. Lajolo. 2006. Isoflavones in processed soybean products from ecuador. Braz. Arch. Biol. Technol. 49:853-859.

Huuskonen, A., P. Lamminen and E. Joki-Tokola. 2009. The effect of concentrate level and concentrate composition on the performance of growing dairy heifers reared and finished for beef production. Acta Agric. Scand. 59:220-229.

Inada, S., T. Kola and Y. Isozaki. 2003. Composition and digestive characteristics of steam dried Tofu cake for feed of cattle. The West Japan Journal of Animal Science 46:23-27.

Jia, Z. H., T. Sahlu, J. M. Femandez, S. P. Hart and T. H. Teh. 1995. Effects of dietary protein level on performance of Angora and cashmere-producing Spanish goats. Small Rumin. Res. 16: 113-119.

Kato Y. 1988. Shiryo Bunseki kijun tyuukai. Nihon Shiryo Kyoukai, Tokyo.

Kokkonen, U. M., P. Riskilä, M. T. Roihankorpi and T. Soveri. 2001. Circadian variation of plasma atrial natriuretic peptide, cortisol and fluid balance in the goat. Acta Physiol. Scand. 171:1-8.

Lengemann, F. W. and N. N. Allen. 1955. The development of rumen function in the dairy calf: 1 . Some characteristics of the rumen contents of cattle of various ages. J. Dairy Sci. 38:651656.

Mbassa, G. K. and J. S. D. Poulsen. 1991. The influence of pregancy, lactation and environment on hematological values in Danish Landrace goats (Capra Hircus) of different parity: 1. Electrolytes and enzymes. Comp. Biochem. Physiol. 100:413422.

NARO. 2010. Standard tables of feed composition in Japan (2009). National Agriculture and Food Research Organization, Tokyo, JAPAN. pp. 80-93.
Negesse, T., M. Rodehutscord and E. Pfeffer. 2001. The effect of dietary crude protein level on intake, growth, protein retention and utilization of growing male Saanen kids. Small Rumin. Res. 39:243-251.

NRC. 2006. Nutrient requirements of small ruminants. National research council. The national academies. Washington, DC, USA. pp. 271-299.

Okada, T., T. Sugishita, T. Murakami, H. Murai, T. Saikusa, T. Horino, A. Onoda, O. Kajimoto, R. Takahashi and T. Takahashi. 2000. Effect of the defatted rice germ enriched with GABA for sleeplessness, depression, autonomic disorder by oral administration. Nippon Shokuhin Kagaku Kogaku Kaishi (Jpn.) 47:596-603.

Pathak, N. N., N. Kewalramani and D. N. Kamra. 1992. Intake and digestibility of oats (Avena sativa) and berseem (Trifolium alexandrinum) in adult black buck (Antilope cervicapra). Small Rumin. Res. 8:265-268.

Saeki, M. 2007. The characteristic and the utilization of Eco-feed for swine. Proceedings of Japanese Society for Animal Nutrition and Metabolism 51:15-20.

SAS. 1990. SAS/STAT user's guide: Volume 2, Version 6. 4th Ed. SAS Institute Inc., SAS Campus Drive, Cary, NC 27513.

Scott, B., M. Clements, C. Griffiths and J. Ihrig. 2009. Biofuels impact on crop and food prices: Using an interactive spreadsheet. International Finance Discussion Papers 967:1-30.

Skotinicka, E., Z. Muszczyński and M. Suska. 2011. Effect of the periparturient period on serum lipid and cholesterol lipoprotein concentrations in goat (Capra Hircus). Acta Vet. Hung. 59: 445-454.

Takaya, Y., T. Furukawa, S. Miura, T. Akutagawa, Y. Hotta, N. Ishikawa and M. Niwa. 2007. Antioxidant constituents in distillation residue of Awamori spirits. J. Agric. Food Chem. 55:75-79.

Tamaki, M., H. Shimabukuro, S. Okano and T. Namihira. 2005. The availability of Awamori-moromi vinegar residues as the dairy cattle feed. The West Japan Journal of Animal Science 48:65-67.

Tang, C. H., C. S. Chang, T. W. Tan, S. C. Liu and J. F. Liu. 2010. The novel isoflavone derivatives inhibit RANKL-induced osteoclast formation. Eur. J. Pharmacol. 648:59-66. 